Vol. 1, No. 2, Desember 2020

DOI: https://doi.org/10.35311/jmpm.v1i2.11

ISSN: 2722-4902 | e-ISSN: 2745-3588
Jurnal Mandala

Pengabdian Masyarakat

Journal homepage:https://jurnal-pharmaconmw.com/jmpm

\title{
Jahe Peningkat Sistem Imun Tubuh di Era Pandemi Covid- 19 di Kelurahan Kadia Kota Kendari
}

\author{
Ratna Umi Nurlila1*, Jumarddin La Fua² \\ 1STIKES Mandala Waluya Kendari \\ ${ }^{2}$ Institut Agama Islam Negri Kendari
}

\begin{abstract}
ABSTRAK
Covid-19 adalah penyakit baru yang telah menjadi pandemik, penyakit ini harus diwaspadai karena penularan yang relatif cepat, memiliki tingkat mortalitas yang tidak dapat diabaikan. Hingga saat ini kasus penderita virus covid-19 terus mengalami peningkatan, kasus di Sulawesi Tengara mencapai 3.568 kasus terkonfirmasi positif, kasus sembuh mencapai 2.348 orang dan kasus meninggal 66 orang. Kasus ini di duga akan terus mengalami peningkatan jika kesadaran masyarakat dalam pematuhan protokol kesehatan tidak dilaksanakan. Di samping itu perlu upaya peningkatan sistem imun tubuh mengingat virus dapat masuk ke dalam tubuh manusia pada saat imun mengalami penurunan. Sistem imun tubuh penting untuk di jaga dalam era covid-19 seperti saat ini, salah satu sumber daya alam yang cukup melimpah di Sulawesi Tenggara dengan harga yang murah dan memiliki kandungan antioksidan yang cukup tinggi adalah rimpang jahe.Rimpang jahe ini banyak di jumpai di pasar tradisional dan petani di samping itu di dalam rimpang jahe banyak sekali kandungan senyawa aktif yang menyehatkan bagi tubuh, di tengah keterbatasan suplai produksi vitamin $\mathrm{C}$ dan sulit terjangkaunya bagi masyarakat menengah ke bawah rimpang jahe ini sangat membantu masyarakat dalam meningkatkan sistem imun. Kegiatan pengabdian masyarakat ini yang dilaksanakan di kelurahan Kadia, Kecamatan Kadia, kota Kendari. Tujuan kegiatan ini adalah untuk memberikan edukasi dan mengajak masyarakat untuk patuh terhadap protokol kesehatan dan menjaga sistem imun tubuh dengan mengkonsumsi jahe dan beberapa produk olahan jahe, serta melakukan penanaman jahe di pekarangan rumah sebagai sarana penyediaan jahe untuk keluarga.Pengabadian ini penting dilakukan mengingat sejak Juni hingga Oktober terjadi peningkatan jumlah kasus positif Covid-19 khususnya di daerah ini. Melalui kegiatan ini diharapkan ibu rumah tangga di kelurahan Kadia Kecamatan Kadia sebagai kelompok mitra dapat memahami pentingnya menjaga sistem imun tubuh khususnya di era pandemik covid-19 dengan mengkonsumsi olahan rimpang jahe yang terjangkau dan mudah. Selain itu, diharapkan kepada masyarakat untuk dapat memanfaatkan pekarangan rumah bukan sebagai aspek keindahan tetapi aspek kesehatan dengan menanam tanaman obat di pekarangan rumah.

Kata Kunci :Jahe, Sistem imun, Pandemik, Covid-19, Kota Kendari
\end{abstract}

\section{Ginger Improves the Body's Immune System During a Pandemic Covid-19 in a Village in Kendara City}

\section{ABSTRACT}

Covid-19 is a new disease that is making headlines and is highly infectious. Transmission is rapid and has a high mortality rate. This virus continues to infect sufferers; cases in Sulawesi are now at 3,568, 2,348 recovered cases, and 66 deaths. It is suspected that this case will continue to increase if public awareness of complying with health protocols is not implemented. It is also important to increase how the body's immune system works in order to prevent the virus from entering the body. The body's immune system is important to maintain during a pandemic like this time, one of the abundant natural resources in Southeast Sulawesi which is cheap and has a high antioxidant content is ginger. This is a common ingredient in traditional medicine. In addition, in the ginger rhizome contains a lot of active compounds that are healthy for the body, in the midst of limited supply of vitamin C production and it is difficult to reach for the middle to lower middle class, this ginger rhizome really helps people to improve their immune system. The community service is in Kadia Village, Kadia District, Kendari City. The purpose of this activity is to offer education and stimulate people to adhere to health protocols and maintain their bodies' immune systems by consuming ginger and several ginger products, as well as planting ginger in the yard for consumption. The reason why examining and preserving the body of the person has become important is because, in a short time, around June to around October, there has been an increase in the number of positive cases of Covid-19, especially in this area. Through this activity, it is our hope that housewives from Kadia Village, Kadia District, can better understand how important it is to maintain the immune system, especially in the Covid-19 pandemic era by consuming affordable and easy processed ginger root. Additionally, we hope that the community can take advantage of the neighborhood's backyard as a new source of medicine by planting different medicinal plants in the yard.

Keywords: Ginger, Immune System, Pandemic, Covid-19, Kendari City

Penulis korespondensi

Ratna Umi Nurlila

STIKES Mandala Waluya Kendari

E-mail :ratna_stikesmw@yahoo.com

No. Hp 085241698208 
PENDAHULUAN

Sejak kemunculan wabah virus covid19 di Indonesa yang selanjutnya menyebar di beberapa wilayah Indonesia khususnya Sulawesi Tengara pada bulan mei 2020, berbagai upaya pemerintah dilakukan demi mencegah penularan virus, mengingat penyebaran dan penularan virus covid-19 yang sangat cepat, maka pemerintah mulai melakukan proposi kepada segenap lapisan masayarakat untuk melakukan social distanding, mengunakan masker bila keluar rumah, kebiasaan cuci tangan hingga menjaga sistem imun tubuh, mengigat sifat virus covid-19 menyerang sistem imun tubuh manusia, WHO (2020).

Covid-19 adalah penyakit baru yang telah menjadi pandemic, penyakit ini harus diwaspadai karena penularan yang relatif cepat, memiliki tingkat mortalitas yang tidak dapat diabaikan, dan belum adanya terapi definitive, WHO (2020). Gejala utama yang muncul seperti demam, batuk, dapat disertai dengan nyeri tenggorok, kongesti hidung, malaise, sakit kepala, dan nyeri otot. Selain itu, pada beberapa kasus ditemui tidak disertai dengan demam dan gejala relatif ringan, Sherren.,et al (2020).

Hingga saat ini kasus penderita virus covid-19 terus mengalami peningkatan, kasus di Sulawesi Tengara mencapai 3.568 kasus terkonfirmasi positif, kasus sembuh mencapai 2.348 orang dan kasus meningal 66 orang.( Media Indonesia dalam covid-19, 2020). Kasus ini di duga akan terus mengalami peningkatan jika kesadaran masyarakat dalam pematuhan protokol kesehatan yang telah di sampaikan tidak dilaksanakan, Athena, $d k k$ (2020).

Bukan hanya itu saja wabah virus covid-19 ini bahkan menyebabkan lesunya perekonomian dan pelaksanaan pendidikan yang beralih melalui mekanisme oneline, Nasution, $d k k$ (2020) Jika tidak dilakukan penaganan secara serius tidak mustahil suatu daerah akan terpuruk karena wabah virus covid-19 ini. Bentuk upaya promosi dilakukan dalam hal ini, dan tidak terlepas dari upaya pemutusan mata rantai penularan dan menghentikan penularan, yang salah satunya dapat dilakukan dengan upayapeningkatan sisitem imun tubuh, Shi, et al (2020).

Sistem imun tubuh penting untuk di jaga dalam era covid-19 seperti saat ini, selain mengkonsumsi nutrisi yang cukup istirahat yang teratur suplemen yang banyak mengandung vitamin $\mathrm{C}$ sebagai sumber antioksidan baik untuk di konsumsi. Salah satu sumberdaya alam yang melimpak di sultra dengan harga yang murah dan memiliki kandungan antioksidan yang cukup tinggi adalah rimpang jahe, rimpang jahe ini banyak di jumpai di pasar tradisional dan petani di samping itu di dalam rimpang jahe banyak sekali kandungan senyawa aktif yang menyehatkan bagi tubuh, di tengah keterbatasan suplai produksi vitamin C dan sulit terjangkaunya bagi masyarakat menengah ke bawah rimpang jahe ini sangat membantumasyarakat menengah kebawah dalam meningkatkan sistem imun dengan mengkonsumsinya Aryanta, (2019). Dalam penelitian yang dilakukan Nurlita dan Setyabudi (2018) juga 
disampaikan bahwa ekstrak jahe dapat memperbanyak sel pembuluh alami natural killer dan menghancurkan dinding sel virus yang telah menginfeksi inangnya, dalam tubuh manusia.

Dengan semakin meningkatnya jumlah penderita terkonfirmasi positif covid-19 di wilayah Sulawesi tengara khusunya di kota kendari, dan menurunya kesadaran masyarakat dalam mematuhi protokol kesehatan, seperti mengunakan masker, menghindari kerumunan atau atur jarak, membiasakan cuci tangan, maka sangat perlu untuk di ketahui, di pahami dan di lakukan upaya dalam peningkatan sistem imun yang juga mulai menurun, selama ini sitem imun terjaga melalui konsumsi makanan dan istirahat saja, akan tetapi asupan yang meningkatkan antibodi tubuh diharapkan untuk di konsumsi sencara kontinu dan menyeluruh, karena karakter dari virus covid-19 adalah menyerang sistem imun tubuh manusia, Athen $d k k$ (2020) jika sistem imun baik dengan kepatuhan protokol kesehatan yang baik pula maka mata rantai penularan covid-19 dapat di putuskan, lebih-lebih lagi kelurahan kadia kesamatan kadia terletak di tengah kota Kendari yang juga mengalami peningkatan kasus penderita covid-19 ini. Alasan kegiatan pengabdian masyarakat di laksanakan di kelurahan Kadia, Kecamata Kadia Kota Kendari, karena masyarakat daerah ini masuk dalam wilayah perkotaan dengan pemukiman penduduk yang sangat padat juga aktivitas di luar rumah yang begitu padat apalagi ketika di rumah mereka terdapat orang tua mereka yang juga sangat rentan terhadap paparan virus covid 19 ini. Padatnya pemukiman menjadi alasan utama mudahnya penularan virus ini, begitu pula aktivitas kepala rumah tanga di luar rumah dalam mencari nafkah. Jika di lihat dari kebiasaan mengkonsumsi suplemen vitamin $C$ yang susah terjangkau, selain karena perekonomian atau daya beli juga kebutuhan yang sangat byak untuk di penuhi setiap angota keluarga, sehinga dengan memaksimalkan pemanfaatan pekarangan rumah dengan penaman jahe atau setidaknya pemenuhan jahe dalam kebutuhan sehari hari seperti bumbu masak, atau minuman jahe atau bahkan saraba menjadi alternatif dalam meningkatkan sistem imun tubuh, Lentera (2020) mengingat jahe sering di gunakan sebagai bumbu dapur, dan memiliki komponen senyawa kimia yang kompleks dan berpotensi besar sebagai peningkat antibodi Apalagi daerah sulawesi tegara masih banyak memproduksi jahe dengan harga di pasaran yang mudah di jangkau lapisan masyarakat di wilayah ini, dan jika paradigma masyarakat dalam pemenuhan imunitas tercukupi maka diharapkan memutusan mata rantai penularan virus covid-19 juga bisa terputus, dan akan berimplikasi pada pemutusan mata rantai penularan di daerah wilayah Sulawesi tengara bahkan tingkat nasional.

\section{METODE}

Pelaksanaan kegiatan terdiri dari edukasi kepada kelompok mitra yang terdiri dari ibu rumah tangga yang berada di wilayah kelurahan kadia, kecamatan 
kadia kota kendari, selanjutnya di lanjutkan dengan pelatihan pembuatan olahan minuman dari jahe dan melakukan edukasi dan praktek penanaman jahe di pekarangan rumah sebagai apotek hidup. Pelaksanaan kegiatan di laksakan selama 3 hari dan di ikuti oleh 20 ibu rumah tangga yang tersebar di beberapa RT di kelurahan kadia.

\section{HASIL DAN PEMBAHASAN}

\section{Hasil}

Kegiatan pengabdian masyrakat ini di fokuskan mitra ibu rumah tangga yang tingal di kelurahan kadia, dengan tahapan kegiatan pengambian masyarakat meliputi :

a. Transfer ilmu pengetahuan melalui presentesi dan diskusi tentang pentingnya menjaga sistem imun di masa pandemi seperti saat ini dengan menjaga sistem imun tubuh antara lain mengkonsumsi makanan yang penuh nutrisi, istirahat yang cukup serta mengkonsumsi minuman jahe sebagai peningkat sistem imun tubuh dengan bahan yang tersedia melimpah di pasaran dan harga yang relatif murah, hasil dari kegiatan ini mitra dampingan menjadi lebih mengetahui bahkan memahami betapa pentingnya menjaga sistem imun tubuh, dan besarnya manfaat d. dari rempah jahe yang selama ini digunakan dalam rempah masakan terkadang dalam meningkatkan sistem imun tubuh.

b. Melakukan pelatihan pembuatan sejumlah olahan minuman dari produk jahe, sebagai varian minuman yang bukan hanya enak akan tetapi memiliki manfaat dalam kesehatan tubuh bahkan sebagai peningkat sistem imun tubuh, kususnya di era pandemic covid-19 seperti saat ini, varian minuman dalam pelatihan antara lain minuman jahe hangat, wedang uwuh, saraba, dan jamu dengan campuran rimpang kunyit, temulawak dan jahe, dari kegiatan ini mitra mendapatkan skil dalam membuat olahan jahe selain saraba yang menjadi minuman khas Sulawesi tengara dengan bahan dasar jahe, masyarakat dapat mengolah jahe dengan banyak varian.

c. Melakukan pelatihan penanaman rimpang jahe pada polibag yang di simpan pada pekarangan rumah, agar pekarangan rumah lebih di manfaatkan sebagai toga selain taman bungga juga memudahkan masyarakat mitra dalam penyediaan obat, mengingat jahe dapat mengobati batuk dan masuk angin 


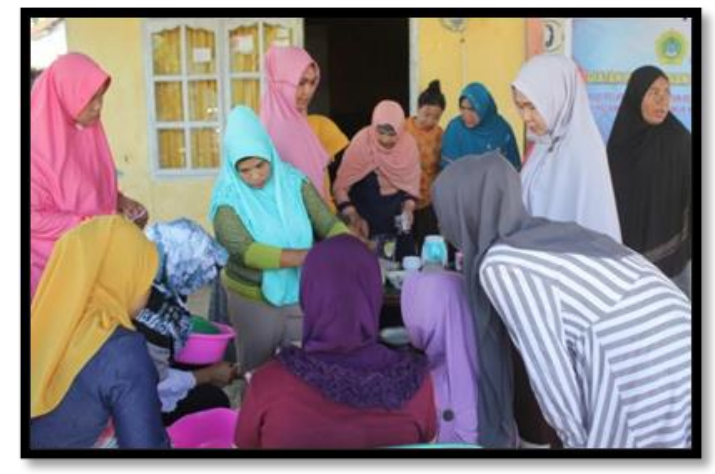

Gambar1.Pelatiahan pembuatan olahan minuman jahe

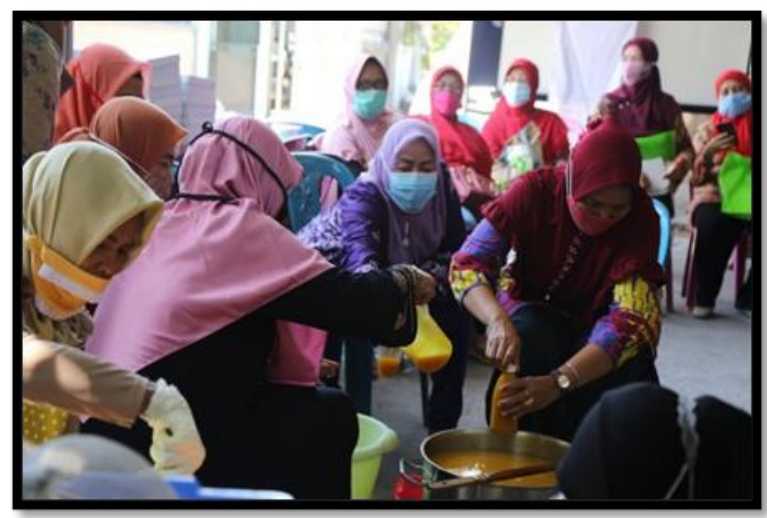

Gambar2. Pelatiahan pembuatan olahan jahe dan empon-empon berupa jamu tradisional sebagai peningkat imun tubuh

\section{PEMBAHASAN}

Dari kegiatan pengabdian masyarakat yang telah di laksanakan di kelurahan kadia kota kendari dengan mitra sasaran dalam program ini adalah ibu rumah tangga di daerah ini. Dimana saat pademi covid-19 seperti saat ini banyak masyarakat tang hanya kwatir tertular namun belum tau apa yang harus di lakukan dalam mencegah penularan, selain keluar mengunakan masker dan kebiasaan mencuci tangan, ada hal yang tidak kalah penting untuk di perhatikan di era seperti saat ini yaitu menjaga sistem imun, dengan cara yang aman, murah dan mudah tersedia yaitu dengan memanfaatkan rimpang jahe, agar nikmat dalam mengkonsumsinya maka perlu olahan yang bisa diterima oleh masyakat mitra. Pelaksana pengabdian kepada masyakat dengan mitra ibu rumah tangga di kelurahan kadia bertujuan untuk meningkatkan pengetahuan dan keaktifan ibu rumah tangga sebagai lider dalam keluarga, yang nantinya dapat bermanfaat bagi dirinya, keluarganya, lingkungan sekitarnya, sampai dengan tingkat Kelurahan, Kecamatan dan akhirnya dapat berkontribusi di tingkat Kota Kendari.

Pada rimpang jahe terkandung senyawa kimia shogaol, gingerol, dan zingeron, capsaicin, farnesene, cineole, caprylic acid, aspartic, linolenic acid, curcurmin, mengandung hingga $4 \%$ minyak atsiri dan juga kandungan oleoresin, di dalam minyak atsiri, masih terdapat 
beberapa unsur alami seperti linalool, methyl heptenone, borneol, cineol, citral, chavicol, geraniol, zingiberene, dan acetates. Gingerol dan curcumin yang sangat baik bagi tubuh. kedua kandungan tersebut berfungsi sebagai antioksidan dan antiinflamasi yang ampuh untuk menangkal radikal bebas sehinga akan meningkatkan sistem imun tubuh. Melalui peningkatan pengetahuan masyarakat kususnya pada mitra kelompok dampingan tentang kandungan dan manfaat dari rimpang jahe, serta jenis olahan yang mudah di buat dan di konsumsi, dengan harga yang murah, sagat di harapkan masuyarakat akan mudah mengapiliaksikan dalam keseharian, sehingga keluarga dapat terhindar dari penyebaran virus corona yang saat ini dapat menular dan mengacam jiwa semua orang.

Program ini diawali dengan pemberitahuan kegiatan kepada lurah Kadia sebagai tempat pelaksanaan program di wilayah Kelurahan kadia Kecamatan kadia Kota Kendari. Selanjutnya, dilakukan persiapan rangkaian kegiatan yang dilakukan selama 2 hari, yaitu pemberian materi dan pelatihan pembuatan olahan terhadap mitra dampingan kegiatan pengabdian masyakat. Selanjutnya mempersiapkan bahan, materi, dan peralatan penunjang untuk pelaksanaan penyuluhan, pelatihan, praktik pembuatan olahan minuman rimpang jahe dibantu oleh mahasiswa. Pelaksanaan program ini terdiri dari dua tahapan, yaitu penyuluhan dan praktek langsung. Penyuluhan dilakukan untuk memberi informasi seputar pengetahuan pentingnya menjaga imun tubuh dei era pandemic covid-19 dan manfaat dari rimpang jahe dalam meningkatkan imunitas

dan

kesehatan

tubuh.Selanjutnya pelatihan pembuatan olahan rimpang jahe menjadi olahannya dilakukan di salah satu rumah warga yang melibatkan dosen dan mahasiswa Universitas Mandala Waluya. Selanjutnya dilakukan penanaman jahe ripang di pekarangan rumah untuk memaksimalkan pekarangan dengan penanaman pada polibag, penanaman rimpang jahe di pekarangan rumah sebagai upaya menghidupkan apotek hidup yang jauh dari kebiasaan masyarakat perkotaan.

Dari kegitan ini terjadi peningkatan pengetahuan yang signifikan menunjukkan bahwa program ini berhasil dan sesuai target yang diharapkan. Sesuai dengan target awal program ini adalah tersampaikannya transfer ilmu dan keterampilan terkait pembuatan olahan minuman jahe sebagai minuman peningkat imunitas dan minuman kesehatan, apalagi saat ini terjadi peningkatan kasus positif corona, meningat kelurahan kadia berada di perkotaan dengan kepadatan hunian yang menjadi rentan terhadap angka penularan. Sehinga melalui program ini mitra dampingan dapat mengaplikasikan ilmu dan pengalaman yang di peroleh dalam rangka menjaga keluarga dan linngkungan dari penyakit menular covid19 melalui konsumsi minuman yang memiliki sistem imun tinggi, dan imlu yang di peroleh dapat di tularkan kepada lingkungan yang lebih luas, sehinga secara khusu kelurahan kadia dan secara umum masyarakat kota kendari dapat terhindar dari penularan virus corona, 
dan rantai penularan dapat terputuskan sehinga daerah ini terbas dari viruscorona. Olahan minuman dari bahan baku jahe terdiri dari minuman jahe hangat dengan komposisi jahe yang di bersihkan lalu di keprek dan di panaskan pada air mendidih selama 15 menit, olahan jamu dengan komposisi temu lawak, kunyit, kencur, asam jawa, dan jahe merah di parut lalu diperas mengunakan air masak yang hangat untuk mengeluarkan pati rimpang. Semua olahan tersebut di olah secara tradisional dan di harapkan masyarakat mudah dalam pengunaanya dalam keseharian.

\section{KESIMPULAN}

Melalui kegiatan ini ibu rumah tangga di kelurahan kadia kecamatan kadia sebagai mitra dampingan mengetahui pentingnya menjaga sistem imun tubuh kususnya di era pandemic covid-19 saat ini dengan mengkonsumsi olahan rimpang jahe yang terjangkau dan mudah di dapat dengan bahan berlimpah, serta lebih memanfaatkan pekarangan rumah bukan sebagai aspek keindahan tetapi aspek kesehatan dengan membuat toga pada pekarangan rumah melalui penanaman jahe pada polibag-polibag.

\section{UCAPAN TERIMAKASIH}

Dalam kegiatan pengabdian masyarakat ini tim pengucapkan terimakasih kepada semua pihak yang membantu jalannya proses pengabdian sehinnga berjalan dengan lancar dan sesuai dengan fokus pengabdian, tak lupa ucapak terimkasih kepada pemerintah setempat dan mitra dampingan yang telah mengikuti kegiatan ini hingga selesai dengan penuh antusius dan maksimal.

\section{DAFTAR PUSTAKA}

Aryanta, I. W. R. (2019). Manfaat Jahe UntukKesehatan. Widya

Kesehatan, 1(2), 39-43.

Athena, A., Laelasari, E., \& Puspita, T. (2020).Pelaksanaan Disinfeksi Dalam Pencegahan Penularan Covid-19 Dan Potensi Risiko Terhadap Kesehatan Di Indonesia. Jurnal Ekologi Kesehatan, 19(1), 1-20.

Chen, H., Guo, J., Wang, C., Luo, F., Yu, X., Zhang, W., ...\& Liao, J. (2020). Clinical characteristics and intrauterine vertical transmission potential of COVID-19 infection in nine pregnant women: a retrospective review of medical records. The Lancet, 395(10226), 809-815.

Lentera, T. (2002). Khasiat dan manfaat jahe merah si rimpang ajaib.AgroMedia.

Nasution, D. A. D., Erlina, E., \& Muda, I. (2020). Dampak Pandemi COVID19 terhadap Perekonomian Indonesia. Jurnal Benefita:

Ekonomi Pembangunan,
Manajemen Bisnis \& Akuntansi, 5(2), 212-224.

Nurlita, D., Handayani, N., \& Setiyabudi, L. (2018).Pembuatan Serbuk Jahe sebagai Minuman Kesehatan Bagi Warga Kelurahan Kahuripan Kecamatan Tawang Kota 
Tasikmalaya.JCES (Journal of Character Education Society), 1(1), 67-73.

Rothan, H. A., \& Byrareddy, S. N. (2020).The epidemiology and pathogenesis of coronavirus disease (COVID-19) outbreak. Journal of autoimmunity, 102433.

Shereen, M. A., Khan, S., Kazmi, A., Bashir, N., \& Siddique, R. (2020). COVID19 infection: Origin, transmission, and characteristics of human coronaviruses. Journal of Advanced Research.

Shi, Y., Wang, Y., Shao, C., Huang, J., Gan, J., Huang, X., ...\& Melino, G. (2020). COVID-19 infection: the perspectives on immune responses.

World Health Organization. (2020). Coronavirus disease ( COVID-19): weekly epidemiological update.

World Health Organization. (2020). Coronavirus disease 2019 (COVID19): situation report, 82. 